\title{
Morphology of the lingual papillae in the fishing cat
}

\author{
By \\ Shoichi EMURA ${ }^{1}$, Toshihiko OKUMURA ${ }^{2}$ and Huayue CHEN ${ }^{3}$ \\ ${ }^{1}$ Nursing Course, Gifu University School of Medicine, Gifu 501-1193, Japan \\ ${ }^{2}$ Technical Section, Gifu University School of Medicine, Gifu 501-1194, Japan \\ ${ }^{3}$ Department of Anatomy, Gifu University Graduate School of Medicine, Gifu 501-1194, Japan \\ - Received for Publication, November 15, $2013-$
}

Key Words: fishing cat, lingual papillae, scanning electron microscopy

\begin{abstract}
Summary: We examined the dorsal lingual surface of an adult fishing cat (Prionailurus viverrinus) by scanning electron microscopy. The filiform papillae on the lingual apex had several pointed processes. The connective tissue core of the filiform papillae resembleda a well in shape. The filiform papillae on the anterior part of the lingual body were large and cylindrical in shape. The connective tissue core of the filiform papillae consisted of a large conical papilla. The filiform papillae on the central part of the lingual body were large and conical. The connective tissue core of the filiform papillae consisted of a large main process and some secondary processes. The connective tissue core of the fungiform papillae did not have processes. The vallate papillae were surrounded by a groove and a pad. The top of the connective tissue core of the vallate papillae had a rough surface with no spines.
\end{abstract}

\section{Introduction}

Many studies have reported on the structures of the lingual surfaces in various animals. In the order Carnivora, there have been some scanning electron microscopy (SEM) studies on the tongues of the cat (Boshell et al., 1982), dog (Iwasaki and Sakata, 1985), mongoose (Iwasaki et al., 1987), Japanese weasel (Furubayashi et al., 1989), sea otter (Shimoda et al., 1996), bush dog (Emura et al., 2000), panther and Asian black bear (Emura et al., 2001), lion (Emura et al., 2003), tiger (Emura et al., 2004) and jaguar (Emura et al., 2013). Such studies have revealed variations in the morphology and distribution of papillae on the dorsal lingual surface among animal species.

However, no SEM study of the tongue of the fishing cat has been carried out. The purpose of this study is thus to examine three-dimensionally the dorsal lingual surface of the jaguar, in order to compare the results with those of previous reports on other mammals.

\section{Materials and Methods}

The tongue of one adult fishing cat (Prionailurus viverrinus) of the family Felidae was used in this study. The tongue was fixed in $10 \%$ formalin. Small blocks containing papillae were cut with a razor blade and post-fixed with $1 \%$ osmium tetroxide for $1 \mathrm{~h}$. Thereafter, the specimens were dehydrated through a graded series of acetone and critical-point-dried. To show the three-dimensional connective tissue structure of the lamina propria of the mucosa, some of the samples were washed in distilled water after fixation and macerated in $3.5 \mathrm{~N} \mathrm{HCl}$ at $35^{\circ} \mathrm{C}$ for three days. After maceration, the tissues were washed in distilled water, post-fixed in $1 \%$ osmium tetroxide for $1 \mathrm{~h}$, and dehydrated in a series of acetone and critical-point-dried. All specimens were sputtered with Pt-Pd before being examined by SEM (Hitachi S-3500N, Tokyo, Japan) at an accelerating voltage of $10 \mathrm{kV}$.

\section{Results}

Macroscopically, the tongue of the fishing cat was about $12 \mathrm{~cm}$ long. Filiform papillae were distributed over the entire dorsal surface of the lingual body (Fig. 1). Fungiform papillae were round in shape and more densely distributed on the tip of the lingual apex. There were no foliate papillae. Vallate papillae were located on both sides of the posterior end of the lingual body, and there were 


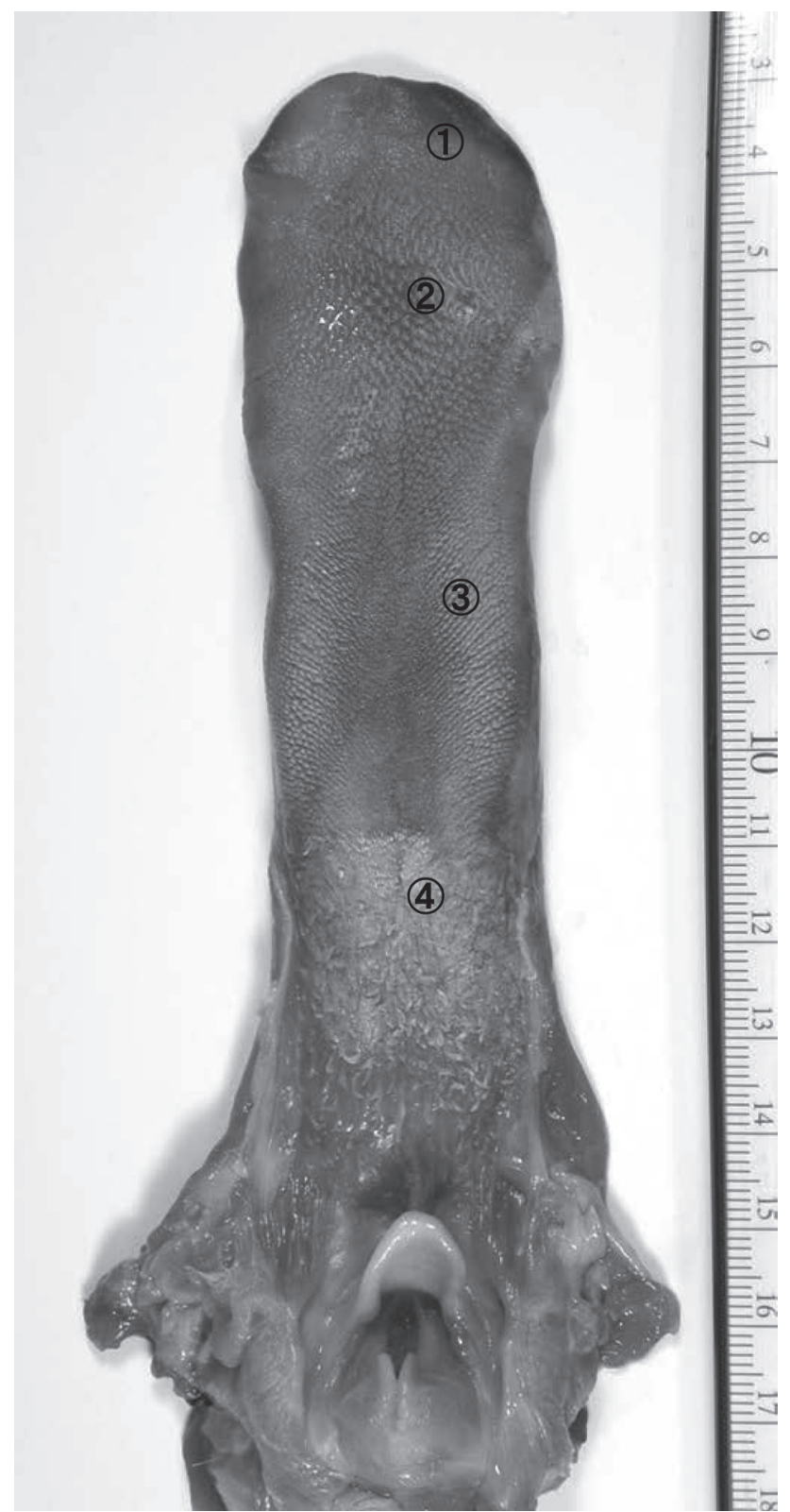

Fig. 1. Macrograph of a fishing cat tongue. (1), (2), (3) and (4) show the parts prepared for SEM.

four vallate papillae in total.

By SEM, the filiform papillae on the lingual apex had several pointed processes (Fig. 2a). The connective tissue core of the filiform papillae resembled a well in shape (Fig. $2 b)$. The filiform papillae on the anterior part of the lingual body were large and cylindrical in shape (Fig. 2c). The connective tissue core of the filiform papillae consisted of a large conical papilla (Fig. 2d). The filiform papillae on the central part of the lingual body were large and conical (Fig. 3a). The connective tissue core of the filiform papillae consisted of a large main process and some secondary processes (Fig. 3b). The connective tissue core of the fungiform papillae did not have processes (Fig. 3b). The vallate papillae were surrounded by a groove and a pad (Fig. 3c). The top of the connective tissue core of the vallate papillae had a rough surface with no spines (Fig. 3d).

\section{Discussion}

Shimoda et al. (1996) reported that the filiform papillae on the margin of the tongue of a newborn sea otter were divided into two shapes: horned and club-shaped, while the fungiform papillae were also divided into two shapes: hemispherical and club-shaped. Emura et al. $(2001,2003)$ reported that large papillae were observed on the margins of the lingual apexes of a newborn panther, newborn Asian black bear and lion. In the cat (Boshell et al., 1982), newborn panther (Emura et al., 2001), lion (Emura et al., 2003), tiger (Emura et al., 2004) and jaguar (Emura et al., 2013), a marked transition occurred between the tip and midportion of the dorsum of the tongue. This transition was characterized by an increase in size of the projections of the filiform papillae. In the midportion of the tongue, these projections were very prominent. This finding is fairly consistent with the observations of the tongue of the fishing cat. Furthermore, the marked regional variation in size and morphology of the filiform papillae in the fishing cat tongue contrasts with the descriptions in plant-eating animals. The filiform papilla on the lingual apex consisted of a large main papilla and some secondary papillae in the jaguar (Emura et al., 2013). The connective tissue core of the filiform papilla was mountain-like in shape (Emura et al., 2013). However, the filiform papilla on the lingual apex had several pointed processes in the fishing cat. The connective tissue core of the filiform papilla resembled a well in shape.

Many studies have reported on the three-dimensional structure of the vallate papillae in the mammalian tongue. Several studies have indicated that the vallate papillae were flattened and oval in shape and were surrounded by a groove and a pad (Krause and Cutts, 1982; Chamorro et al., 1986; Qayyum et al., 1988; Chunhabundit et al., 1992; Agungpriyono et al., 1995; Atoji et al., 1998; Emura et al., 2013). The vallate papillae of the cat, dog and flying squirrel were found to be encircled by the filiform papillae in the posterior body (Boshell et al., 1982; Iwasaki and Sakata, 1985; Emura et al., 1999). Equine vallate papillae were composed of a primary papilla that was divided into several secondary papillae by intermediate grooves (Chamorro et al., 1986). Occasionally, in bovine vallate papillae, twin papillae were surrounded only by a primary papillary groove (Chamorro et al., 1986). The vallate papillae of the bush dog were surrounded by a groove and a crescent pad, and on the dorsal surfaces of the papillae, small conical papillae were observed. In addition, some vallate papillae of the Asian black bear were shown to 

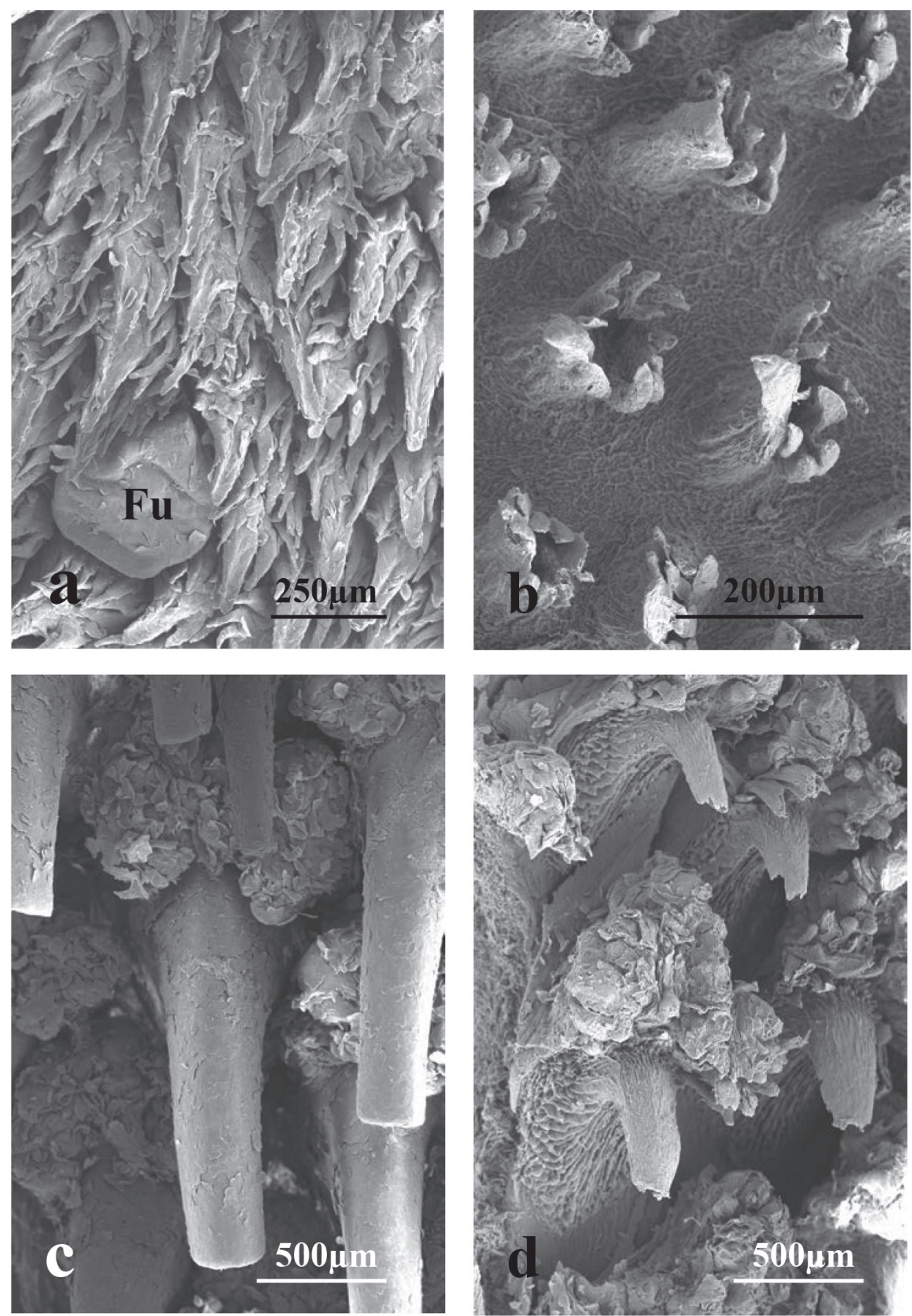

Fig. 2. (a, b) SEM micrographs of (1) in Fig. 1. The filiform papillae on the lingual apex have several pointed processes. The connective tissue core of the filiform papillae are resembled a well in shape. (c, d) SEM micrographs of (2) in Fig. 1. The filiform papilla on the anterior part of the lingual body is large and cylindrical in shape. The connective tissue core of the filiform papilla consists of a large conical papilla. Fu $=$ fungiform papilla.

be composed of primary papillae that were divided into several secondary papillae by intermediate grooves (Emura et al., 2001). The structure of the vallate papillae in the fishing cat was similar to that of the jaguar reported by Emura et al. (2013).
The number of vallate papillae has been reported in many vertebrates. On the tongue of the tiger, Emura et al. (2004) observed four vallate papillae. In contrast, five vallate papillae were observed in the bush dog (Emura et al., 2000). There were ten in the panther and seven or 

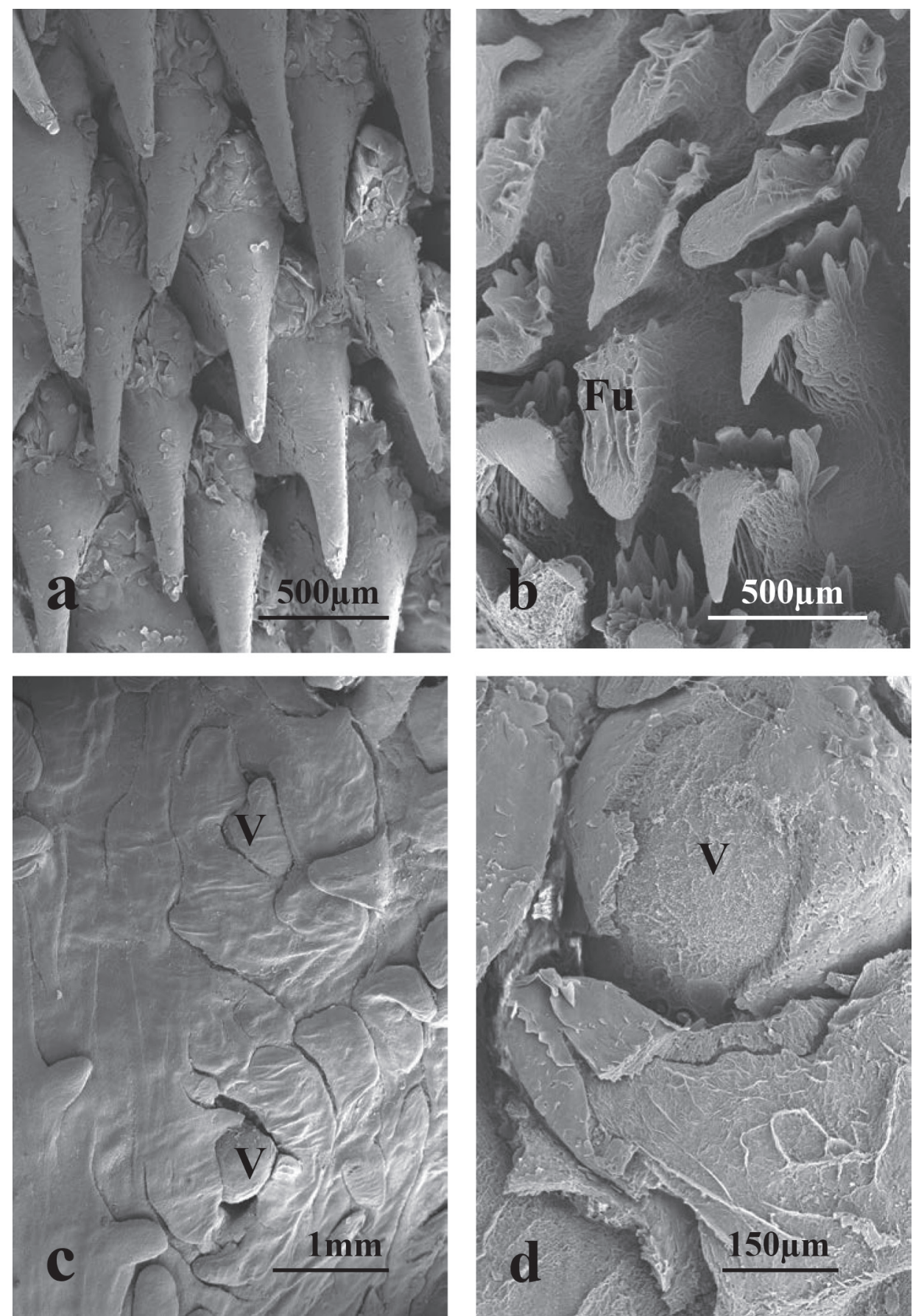

Fig. 3. (a, b) SEM micrographs of (3) in Fig. 1. The filiform papilla on the central part of the lingual body is large and conical. The connective tissue core of the filiform papilla consists of a large main process and some secondary processes. The connective tissue core of the fungiform papilla (Fu) does not have processes. (c, d) SEM micrographs of (4) in Fig. 1. The vallate papillae (V) are surrounded by a groove and a pad. The top of the connective tissue core of the vallate papillae $(\mathrm{V})$ has a rough surface with no spines.

eight in the Asian black bear (Emura et al., 2001). Five to nine vallate papillae were observed in the lion (Emura et al., 2003). Seven vallate papillae were observed in the jaguar (Emura et al., 2013). In this study, four vallate papillae were observed in the fishing cat. Further studies are required to clarify the relationship between the species and the number of vallate papillae.

In conclusion, the morphological characteristics of the tongue in the fishing cat, for which the staple food is fish, were shown to be similar to those of animals in other members of the Felidae. 


\section{Acknowledgements}

We are grateful to the staff of Tennoji Zoo, Osaka, Japan for supplying the specimen.

\section{References}

1) Atoji $Y$, Yamamoto $Y$ and Suzuki Y. Morphology of the tongue of a male Formosan serow (Capricornis crispus swinhoei). Anat Histo1 Embryol 1998; 27:17-19.

2) Agungpriyono S, Yamada J, Kitamura N, Nisa C, Sigit K and Yamamoto Y. Morphology of the dorsal lingual papillae in the lesser mouse deer, Tragulus javanicus. J Anat 1995; 187:635-640.

3) Boshell, J.L, Wilborn W.H and Singh B.B. Filiform papillae of cat tongue. Acta Anat 1982; 114:97-105.

4) Chamorro C.A, de Paz P, Snadval J and Fernandez J.G. Comparative scanning electron-microscopic study of the lingual papillae in two species of domestic mammals (Equus caballus and Bos Taurus). I. Gustatory papillae. Acta Anat 1986; 125:83-87.

5) Chunhabundit $P$, Thongpila $S$ and Somana R. SEM study on the dorsal lingual surface of the common tree shrew, Tupaia glis. Acta Anat 1992; 143:253-257.

6) Emura S, Hayakawa D, Chen H and Shoumura S. Morphology of the dorsal lingual papillae in the newborn panther and Asian black bear. Okajimas Folia Anat Jpn 2001; 78:173-178.

7) Emura S, Hayakawa D, Chen H and Shoumura S. SEM and gross study on the lingual surface of the lion, Panthera leo (in Japanese). Mammalian Science 2003; 43:45-50.

8) Emura S, Hayakawa D, Chen H and Shoumura S. Morphology of the lingual papillae in the tiger. Okajimas Folia Anat Jpn 2004; 81:39-44.

9) Emura S, Okumura T, Chen H. Morphology of the lingual papillae in the jaguar. Okajimas Folia Anat Jpn 2013; 89:93-97.

10) Emura S, Tamada A, Hayakawa D, Chen H, Jamali M, Taguchi H and Shoumura S. SEM study on the dorsal lingual surface of the flying squirrel, Petaurista leucogenys. Ann Anat 1999;181:495498.

11) Emura S, Tamada A, Hayakawa D, Chen H and Shoumura S. Morphology of the dorsal lingual papillae in the bush dog (Speothos venaticus). Okajimas Folia Anat Jpn 2000; 77:137-142.

12) Furubayashi R, Sato $E$ and Ishibashi T. Histological pattern of the tongue in the Japanese weasels, Mustera itatsi, with special reference to the morphology and distribution of papillae, taste buds and lingual glands(in Japanese). Acta Anat Nippon 1989; 64:210-214.

13) Iwasaki S, Miyata K and Kobayashi K. Comparative studies of the dorsal surface of the tongue in three mammalian species by scanning electron microscopy. Acta Anat 1987; 128:140-146.

14) Iwasaki $S$ and Sakata K. Scanning electron microscopy of the lingual dorsal surface of the beagle dog. Okajimas Folia Anat Jpn 1985; 62:1-14.

15) Krause W.J and Cutts J.H. Morphological observations on the papillae of the opossum tongue. Acta Anat 1982; 113:159-168.

16) Shimoda $T$, Nakanishi E, Yoshino $S$ and Kobayashi S. Light and scanning electron microscopic study on the lingual papillae in the newborn sea otter Enhydra lutris. Okajimas Folia Anat Jpn 1996; 73:65-74.

17) Qayyum M.A, Fatani J.A and Mohajir A.M. Scanning electron microscopic study of the lingual papillae of the one humped camel, Camelus dromedaries. J Anat 1988; 160:21-26. 